\title{
KONSEP HARKAT DAN MARTABAT PEREMPUAN \\ DALAM BUKU HABIS GELAP TERBITLAH TERANG \\ KARYA R.A. KARTINI DAN RELEVANSINYA \\ TERHADAP PENDIDIKAN ISLAM
}

\author{
Uliyatul Marfu'ah \\ Universitas Islam Negeri Sunan Kalijaga Yogyakarta
}

Abstract: The background of this research originated from the admiration of the author of the book Habis Gelap Terbitlah Terang by R.A. Kartini who has an extraordinary spirit in fighting for the dignity of women. Women who are not valued, are not recognized, and do no have the opportunity to develop themselves during the R.A. Kartini, now has freedom. His dignity and recognition are recognized by the community. But along with the development of the era that was so extraordinary. Book Habis Gelap Terbitlah Terang began to be forgotten by the people. This research included qualitative research and the type of research that the authors do is library research. The research approach used is the historical approach. The method of data collection in this study is adjusted to the type of research conducted, namely the research library, then the right data collection method is the collection and documentation method. Data analysis in this study uses content analysis method. Based on the results of research conducted by the author about the concept of the dignity of women in view of R.A. Kartini can be concluded that the concept of the dignity of women in the view of R.A. Kartini has seven concepts: educated women, virtuous women, skilled women, free women who are civilized and educated, men collaborate with women, women who are knowledgeable about religion, and delete the caste system in society. The seven concepts have a close relationship to Islamic education which is focused on the goal of Islamic education, namely facilitates women to develop themselves, both in the realm of individuals, families, social and in work so that we create human being.

Keywords: Dignity, Women, Writing of R.A. Kartini and Islamic Education.

Abstrak : Latar belakang penelitian ini berawal dari kekaguman penulis pada buku Habis Gelap Terbitlah Terang karya R.A. Kartini yang memiliki semangat luar biasa dalam memperjuangkan harkat dan martabat perempuan. Perempuan yang tidak dihargai, tidak diakui, dan tidak memiliki kesempatan untuk mengembangkan diri pada masa R.A. Kartini, kini telah memiliki kebebasan. Harkat dan martabatnya terakui oleh masyarakat. Namun seiring perkembangan zaman yang begitu luar biasa. Buku Habis Gelap Terbitlah Terang ini mulai terlupakan oleh masyarakat. Penelitian ini termasuk penelitian kualitatif dan jenis penelitian yang penulis lakukan merupakan penelitian kepustakaan (library research). Pendekatan penelitian yang digunakan yaitu pendekatan sejarah (histori). Metode pengumpulan data dalam penelitian ini disesuaikan dengen jenis penelitian yang dilakukan, yaitu library research maka metode pengumpulan data yang tepat adalah metode pengumpulan dan dokumentasi. Analisis data pada penelitian ini menggunakan metode content analysis. Berdasarkan hasil penelitian yang dilakukan oleh penulis tentang 
konsep harkat dan martabat perempuan dalam pandangan R.A. Kartini dapat disimpulkan bahwa konsep harkat dan martabat perempuan dalam pandangan R.A. Kartini ada tujuh konsep yaitu: perempuan berpendidikan, perempuan berbudi luhur, perempuan berketerampilan, perempuan bebas yang beradab dan terpelajar, laki-laki bekerjasama dengan perempuan, perempuan yang berpengetahuan ilmu agama, serta menghapus sistem kasta di masyarakat. Ketujuh konsep tersebut memiliki hubungan yang erat terhadap pendidikan Islam yang difokuskan pada tujuan pendidikan Islam yaitu memfasilitasi perempuan untuk mengembangkan diri, baik dalam ranah individu, keluarga, sosial dan dalam berkarya sehingga terciptalah insan kamil.

Kata Kunci: Harkat dan Martabat, Perempuan, Tulisan R.A. Kartini dan Pendidikan Islam

\section{A. PENDAhULUAN}

Perempuan pada masa Pemerintahan Kononial Belanda abad ke 20 bertolak belakang dengan kodrat perempuan dalam Islam. Mereka dipandang rendah oleh kaum lekaki. Mereka dianggap budak dan terdeskriminasi baik secara fisik maupun psikis. Keberadaannya dianggap tidak penting dalam masyarakat. Adat istiadat pada masa itu tidak memberikan kesempatan perempuan untuk berpendidikan dan tidak diperbolehkan untuk bekerja di luar rumah, serta menduduki jabatan di masyarakat. Perempuan harus takluk seolah-olah perempuan tidak mempunyai kemauan. Perempuan juga hendaknya bersedia untuk dinikahkan dengan laki-laki pilihan orang tuanya. Kewajiban seorang perempuan hanya mengurus rumah tangga dan mendidik anak-anaknya.(Amelia Fauzia, 2004: 4)

Manusia adalah mahkluk yang paling sempurna jika dibandingkan dengan mahkluk ciptaan Tuhan lainnya. Sejak manusia dilahirkan di bumi sejak itu pula manusia membawa apa itu yang disebut dengan harkat dan martabat. Baik pada laki-laki maupun perempuan. Dalam pandangan Islam, laki-laki dan perempuan ibarat dua sisi rel kereta kehidupan. Islam tidak membedakan laki-laki dan perempuan dari kodrat kemanusiaannya. Keduanya sama-sama diciptakan dari diri yang satu. Laki-laki dan perempuan yang paling mulia adalah yang paling bertakwa. Islam memberikan jaminan sepenuhnya atas hak-hak perempuan. Islam memperlakukan perempuan dengan halus, sehalus perasaan yang dimiliki oleh perempuan. Islam memberinya jalan untuk perempuan menyalurkan emosi dan melampiaskan perasaan-perasaannya itu, baik sebagai istri yang dicintai, sebagai ibu yang pengasih, atau sebagai seorang gadis yang memiliki kepekaan rasa.(Lembaga Darut-Tauhid, 2001: 25-30)

Mengabaikan perempuan sama saja dengan mengabaikan setengah dari potensi yang dimiliki masyarakat, dan melecehkan perempuan sama saja dengan melecehkan seluruh manusia, karena tidak ada seorang manusia pun di dunia ini kecuali Adam dan 
Hawa as yang tidak lahir melalui seorang perempuan. Di kalangan para pemikir kontemporer, sebenarnya tidak ada perbedaan pendapat menyangkut perlunya mendudukkan perempuan pada kedudukan yang sebenarnya, serta memberikan perempuan peranan tidak hanya dalam kehidupan rumah tangga tetapi juga dalam kehidupan bermasyarakat. Kini semua pihak mengakui perlunya kebebasan, kemajuan, keadilan dan pemberdayaan perempuan. Yang mereka perselisihkan adalah batas-batas dari hal-hal tersebut. Ada yang sangat sempit dan ketat, tapi ada juga yang sangat luas dan longgar. (M. Quraish Shihab, 2005:31)

Seiring dengan berkembangnya zaman, perempuan dewasa ini telah memiliki kebebasan untuk berkarya serta berkecimpung dalam masyarakat. Dengan perkembangan zaman yang begitu luar biasa. Buku Habis Gelap Terbitlah Terang karya R.A. Kartini terlupakan oleh masyarakat. Mereka lebih suka dengan dunia maya. Membaca apapun yang sedang menjadi pembicaraan hangat di masayarakat. Dari sanalah buku Habis Gelap Terbitlah Terang ini seperti sudah tidak menarik lagi untuk dikaji. Karena masyarakat telah terlena dengan dunia digital.

Tujuan penulis melakukan penelitian terhadap buku Habis Gelap Terbitlah Terang karya R.A Kartini yaitu untuk mengetahui bagaimana konsep harkat dan martabat perempuan dalam buku tersebut dan bagaimana relevansinya terhadap pendidikan Islam.

\section{B. METODE}

Jenis penelitian yang digunakan oleh penulis yaitu penelitian Pustaka dengan menggunakan metode deskriptif kualitatif, yaitu penulis berusaha untuk mendeskripsikan dan menggambarkan konsep harkat dan martabat perempuan dalam buku Habis Gelap Terbitlah Terang karya R.A. Kartini dan relevansinya terhadap pendidikan Islam. Dalam penelitian ini penulis mengkaji buku Habis Gelap Terbilah Terang yang diterjemahkan oleh Armijn Pane. Kemudian teknik pengumpulan data yang digunakan penulis untuk memperoleh data yang dibutuhkan dalam penelitian ini yaitu dokumentasi. Penulis melakukan analisis data dalam penelitian ini, menggunakan metode analisis kualitatif dengan analisis isi atau content analysis.

\section{KAJIAN TOERI}

\section{Konsep Harkat dan Martabat Perempuan}

Sejarah mencatat bahwa ada masa dimana perempuan dinilai sebagai makhluk kelas dua. Begitu pula dalam masyarakat Hindu, keadaan perempuan tidak lebih baik. 


\section{Uliyatul Marfu'ah}

Ajaran Manu menyatakan bahwa wabah penyakit, racun, ular, api dan kematian lebih baik jika dibandingkan dengan perempuan. Seorang istri wajib mengabdikan diri pada suaminya, sebagaimana dia mengabdi kepada Tuhan. Istri harus berjalan di belakang suaminya, tidak boleh berbicara dan tidak juga makan bersama suaminya, tetapi memakan makanan sisa suaminya. Bahkan sampai abad ke-17, jika seorang suami meninggal dunia maka adat mengharuskan seorang istri untuk dibakar hidup-hidup pada saat mayat suaminya dibakar, atau jika seorang istri menginginkan untuk tetap hidup, sang istri harus menanggung resiko yaitu mencukur rambutnya dan memperburuk wajahnya dengan tujuan suapaya sang istri tidak lagi akan diminati oleh laki-laki. (M. Quraish Shihab, 2005: 113-114)

Pada mulanya perempuan Indonesia mempunyai tempat yang sangat baik, mendapatkan penghargaan dan derajat yang sama dengan laki-laki. Namun setelah munculnya beberapa sebab yang mengakibatkan perempuan mengalami kemunduran. Diantaranya yaitu pada zaman Mataram berkembang feodalisme, yang mana menempatkan istri sebagai lambang status sang laki-laki, menggeser posisi perempuan dari kedudukan subjek menjadi objek. Selain adanya feodalisme, juga terjadinya poligami yang banyak terjadi disetiap lapisan masyarakat, terutama di kalangan orang yang berada. (Hamka Hasan, 2009: 32-36) Pada dekade terakhir ini, di Indonesia telah menggejala lahirnya sebuah kesadaran baru yaitu terkait pentingnya peran perempuan. Bahkan dalam kabinet pemerintah terdapat menteri yang khusus membidangi peranan perempuan, bisa dilihat sejak pemerintahan Orde Baru. Semua itu menunjukkan bahwa peran penting perempuan dalam berbagai aspek, ditengah pergumulan sosial, ekonomi, politik dan pendidikan. (Zainal Abidin, 2015: 9-10)

Semakin berkembangnya zaman, perempuan memiliki karir di luar rumah bukan menjadi hal yang tabu lagi. Perempuan berlomba-lomba meningkatkan prestasi akademik serta meningkatkan soft skill yang dimilikinya. Ruang publik yang awalnya merupakan hal yang tabu bagi seorang perempuan, saat ini dianggap sebagai wadah untuk mengekspresikan dan mengaktualisasikan diri. (Cintra Mustikawati, 2015: 66) Setiap manusia termasuk juga perempuan berangkat dan besar dari bekal yang diberikan oleh masyarakat dimana seseorang tersebut tinggal. Bekal yang didapatkan tersebut diantaranya berupa norma, nilai, hukum, budaya, dan lain sebagainya yang disepakati dalam masyarakat. Jadi masih ada sebagian masyarakat yang menganggap perempuan di bawah laki-laki. Namun, sekali lagi hal tersebut tergantung bagaimana lingkungan orang tersebut tinggal. Perempuan dalam menjalankan perannya di masyarakat tergantung pada budaya di mana dia tinggal. Dari sudut pandang peran antara laki-laki dan perempuan 
keduanya sama-sama melaksanakan peran dalam ranah domestik, sosial, dan publik. Namun kenyataan yang terjadi di masyarakat, perempuan lebih banyak menanggung peran domestik jika dibandingkan dengan laki-laki. (Indah Ahdiah, 2013: 1088)

Mayoritas intelektual dan sejarahwan terutama dari kalangan Islam, mengungkapkan bahwa poisi perempuan pada masa pra-Islam merupakan sebuah gambaran kehidupan yang sangat buram dan memprihatinkan. Perempuan dipandang sebagai makhluk yang tidak berharga, menjadi bagian dari laki-laki (subordinatif), keberadaan perempuan sering dianggap menimbulkan masalah, tidak memiliki independensi diri, hak-hak perempuan dapat dengan mudah dirampas dan ditindas, tubuh perempuan dapat diperjualbelikan atau diwariskan, dan diletakkan dalam posisi marinal, serta pandangan-pandangan yang menyedihkan lainnya. Dalam kondisi demikian, perempuan dianggap sebagai mahkluk yang tidak patut mendapat perlakuan yang manusiawi karena yang dinilai sebagai manusia adalah manusia yang memiliki independensi diri dan memiliki hak-haknya secara penuh serta manusia yang bisa mewarisi dan membeli. Mahkluk yang memiliki sifat yang terakhir ini pada masa itu adalah laki-laki. Bahkan, pada masa itu, mengemukakan pendapatnya sendiri saja masih dianggap tabu sehingga mereka sering tidak memiliki hak penuh dalam menentukan persoalan-persoalan yang seharusnya diputuskan sendiri. Mereka benar-benar tidak berdaya. (Syafiq Hasyim, 2001: 18-19)

Pemahaman yang otoriter terhadap pesan-pesan agama mengakibatkan penistaan terhadap perempuan. Otoritarianisme telah menjadi faham yang mengabsahkan tindakan menggunakan kekuasaan Tuhan yang dilakukan seseorang, kelompok atau institusi untuk menyatakan bahwa pandangan keagamaannya (tafsir atas teks suci) paling benar dan itulah yang sebenarnya dikehendaki Tuhan. Sementara interpretasi yang dikemukakan pihak lain dianggap salah dan bukan kehendak Tuhan atau bahkan pada titik tertentu dituding sesat dan menyesatkan. (Nafriandi, 2016: 61)

Semua hal buruk yang diperoleh perempuan pada masa pra-Islam sedikit demi sedikit hilang dengan datangnya agama Islam. Islam datang membawa pesan moral kemanusiaan yang tidak ada bandingannya dengan agama manapun, tidak hanya mengajak manusia untuk melepaskan diri dari belenggu dan tirani kemanusiaan, Islam lebih jauh mengajak manusia untuk membebaskan diri dari belenggu ketuhanan yang politeis menuju kepada kebebasan dengan satu Tuhan Yang Esa. Misi tauhid inilah yang menyebabkan Islam sangat efektif untuk menjadi basis gerakan transformasi keagamaan. Apabila pada masa sebelum Islam datang, dunia sangat didominasi oleh imperialisme dan 


\section{Uliyatul Marfu'ah}

kolonialisme antar sesama manusia, kelompok, suku, maupun antar bangsa, tetapi denga adanya Islam diikrarkan bahwa semua manusia setara dihadapan Tuhan.

Betapapun, kita harus berkata dan yakin bahwa laki-laki dan perempuan adalah sepasang mahkluk Tuhan yang memiliki marabat dan kadar yang sama, tetapi harus diakui pula bahwa terdapat perbedaan-perbedaan diantara mereka, perbedaan yang tidak mengakibatkan supremasi laki-laki. Melalui perbedaan-perbedaan itu, masing-masing memiliki kemandirian yang pada akhirnya bertujuan mengantar kepada terciptanya hubungan yang harmonis diantara keduanya sebagai prasyarat bagi terwujudnya masyarakat yang penuh kedamaian dan kesejahteran bagi semua pihak. (M. Quraish Shihab, 2005: 119-120)

Jadi dapat disimpulkan bahwa memang dulu perempuan masih dianggap sangat tabu jika beraktifitas di depan publik atau dapat dikatakan hanya boleh beraktifitas dalam ranah domestik. Namun seiring berkembangnya zaman, peran dan keberadaan perempuan sangat dibutuhkan dalam aktifitas publik. Hal tersebut juga telah diterima oleh masyarakat pada umumnya. Jika masih ada masyarakat yang menganggap tabu ketika melihat perempuan berkecimpung di dunia publik maka dapat disimpulkan bahwa masyarakat tersebut memiliki pemahaman yang masih kuat tentang perempuan yang hanya boleh berakfitas dalam ranah domestik dari orang terdahulu.

Kemudian dengan adanya agama Islam yang dibawa oleh Nabi Muhammad SAW memiliki dampak yang baik untuk kehidupan manusia. Tidak ada perbedaan kedudukan antara perempuan dan laki-laki. Semua manusia sama dipandangan Allah, yang membedakan hanyalah satu, tingkat ketaqwaan seseorang.

\section{Pendidikan Islam}

Dalam khasanah pendidikan Islam, pada umumnya pengertian kata pendidikan mengacu kepada term al-tarbiyah, al-ta'dib, dan al-ta'lim. Istilah al-tarbiyah mempunyai arti pendidikan yang ditawarkan harus berproses, terencana, sistematis, memiliki sasaran yang ingin dicapai, ada pelaksana (pendidik), serta memiliki teori-teori tertentu. Kemudian kata dari ta'lim memiliki makna tidak hanya menguasai, dan mengembangkan ilmu, tetapi juga mengembangkan aspek sikap dan tindakan yang sesuai dengan pengetahuan dalam rangka kehidupannya. Adapun kata al-ta'dib memiliki arti, usaha untuk menciptakan situasi dan kondisi sedemikian rupa, sehingga peserta didik terdorong dan tergerak jiwa sekaligus hatinya untuk bersifat yang baik dan berperilaku sopan santun sesuai dengan apa yang diharapkan. Beberapa pendapat ahli pendidikan Islam mengenai pengertian pendidikan Islam yaitu: a. Al-Syailabi mengartikan pendidikan Islam sebagai 
proses mengubah tingkah laku peserta didik pada kehidupan pribadi, masyarakat, serta alam di sekitarnya. b. Muhammad Fadhil al-Jamaly mengungkapkan bahwa pendidikan Islam merupakan upaya mengembangkan, mendorong serta mengajak peserta didik untuk hidup lebih dinamis dengan berdasarkan nilai-nilai yang tinggi dan kehidupan yang mulia. c. Ahmad D. Marimba mendefinisikan pendidikan Islam merupakan bimbingan atau pimpinan secara sadar terhadap perkembangan perkembangan jasmani dan rohani peserta didik oleh pendidik, dengan tujuan terbentuknya kepribadian yang utama (insan kamil). (Al-Rasyidin dan Samsul Nizar, 2005: 32)

Batasan di atas, memberikan gambaran bahwa, eksistensi pendidikan, merupakan sarana vital dalam upaya menumbuh kembangkan daya kreativitas peserta didik, melestarikan nilai-nilai Ilahiyah dan insaniyah, serta membentuk peserta didik yang produktif, yang mana memungkinkan peserta didik untuk bertahan hidup sesuai dengan perkembangan lingkungan di mana ia berada (Arifuddin Arif, 2008: 25). Pendidikan Islam pada dasarnya merupakan proses perubahan menuju ke arah yang positif. Dalam konteks sejarah, perubahan yang positif ini adalah jalan Tuhan yang telah dilakukan sejak zaman Nabi Muhammad SAW. Pendidikan Islam dalam konteks perubahan ke arah yang positif ini identik dengan kegiatan dakwah yang biasanya dipahami sebagai upaya untuk menyampaikan ajaran Islam kepada masyarakat. (Moh. Roqib, 2009: 18-20)

Dalam pandangan Islam, pendidikan harus mengutamakan pendidikan keimanan. Sejarah telah membuktikan bahwa pendidikan yang tidak atau kurang memperhatikan pendidikan keimanan akan menghasilkan lulusan yang kurang baik dalam segi akhlaknya. Akhlak yang rendah tersebut akan sangat berdampak bagi kehidupan bersama, yang mana dapat menghancurkan sendi-sendi kehidupan berbangsa dan bernegara. Lulusan sekolah yang kurang kuat imannya sangat sulit menghadapi kehidupan pada zaman yang semakin penuh dengan tantangan di masa mendatang (Moh. Solikodin Djaelani, 2012: 101). Dalam proses pendidikan, tujuan pendidikan merupakan kristalisasi nilai-nilai yang ingin diwujudkan ke dalam pribadi peserta didik. Oleh karena itu, rumusan tujuan pendidikan harus bersifat komprehensif, mencakup semua aspek, dan terintegrasi ke dalam pola kepribadian yang ideal. Tujuan pendidikan yang paling sederhana adalah "memanusiakan manusia" atau "membantu manusia menjadi manusia" (Heri Gunawan, 2014: 10). Pendidikan agama bertujuan untuk membentuk insan kamil (kesempurnaan insani) yang bermuara pada pendekatan diri kepada Allah dan kebahagiaan dunia dan akhirat. Pendidikan agama juga diharapkan mampu membentuk kesadaran diri peserta didik 


\section{Uliyatul Marfu'ah}

sebagai hamba Allah sekaligus menjalankan tugasnya yaitu sebagai khalifah di bumi. (Abdul Khobir, 2009: 2)

Dengan demikian dapat disimpulkan bahwa pendidikan Islam adalah rangkaian proses memindahkan dan menanamkan ilmu pengetahuan dan nilai-nilai kepada peserta didik melalui pertumbuhan dan pengembangan potensi fitrah yang dimiliki peserta didik, baik aspek spiritual, intelektual, maupun fisiknya, guna keselarasan dan kesempurnaan hidup dalam segala aspeknya sesuai dengan nilai-nilai ajaran Islam. Kemudian tujuan dari pendidikan Islam yaitu pendidikan yang mencakup tujuan jasmaniah, tujuan rohaniah dan tujuan mental. Dari ketiga aspek tujuan tersebut diharapkan mampu membimbing manusia untuk hidup dengan baik di dunia dan dapat meraih surgaNya setelah meningal.

\section{HASIL DAN PEMBAHASAN}

\section{Konsep Harkat dan Martabat Perempuan dalam Pandangan R.A. Kartini}

Berikut ini adalah konsep harkat dan martabat perempuan menurut R.A. Kartini dalam surat-suratnya yang dikirimkan kepada sahabat-sahabat Belandanya yang terangkum dalam satu buku yaitu Habis Gelap Terbitlah Terang:

a. Perempuan Berpendidikan

Menurut R.A. Kartini perempuan wajib memperoleh pendidikan, karena perempuan akan menjadi ibu, yang mana ibulah pendidik yang pertama bagi anakanaknya. Sebelum masuk sekolah ibulah yang menjadi tempat belajar anak-anaknya. Sebagaimana surat R.A. Kartini kepada Nyonya M.C.E. Ovink - Soer awal tahun 1900, berikut:

...Siapa yang paling banyak berbuat untuk yang terakhir, yang paling banyak membantu mempertinggi kadar budi manusia? Wanita, ibu. Karena manusia pertama-tama menerima pendidikan dari seorang perempuan. Dari tangan seorang perempuanlah, anak-anak mulai belajar merasa, berpikir dan berbicara. Didikan pertama kali itu bukan tanpa arti bagi seluruh penghidupan. (Kartini, 2018: 52)

Dengan dididiknya perempuan maka perempuan mampu mendidik anakanaknya dengan baik, sehingga generasi penerus bangsa dapat terjamin kepandaiannya. Dengan begitu perempuan memiliki pengaruh besar terhadap kehidupan manusia, karna dialah pendidik kehidupan manusia yang pertama tersebut. Sebagaimana surat R.A. Kartini kepada Nyonya N. Van Kol pada Agustus 1901, berikut:

Karena saya sangat yakin bahwa perempuan dapat menanamkan pengaruh besar dalam kehidupan masyarakat, maka tidak ada yang lebih baik dan sungguh saya inginkan kecuali dididik dalam bidang pengajaran. (Kartini, 2018: 167)

Selain mengatakan bahwa perempuan memiliki pengaruh yang besar, R.A. Kartini juga mengatakan dalam suratnya kepada Nyonya N. Van Kol juga, bahwa 
dengan didiknya perempuan tujuan suatu bangsa akan cepat terlaksana. Berikut surat tersebut:

Didiklah perempuan Jawa, cerdaskan menurut perasaan dan pikiran. Dengan demikian tuan sekalian akan mendapat teman bekerja yang tangkas dan cakap untuk melaksanakan kerja raksasa tuan yang mulia dan indah, yaitu membuat suatu bangsa beradab, cerdas dan bangkit!. (Kartini, 2018: 169-170)

Tugas perempuan tidak berkutat pada memberikan pendidikan pada anakanaknya semata. Namun perempuan juga memiliki tugas yang lainnya, seperti urusan rumah tangga. Sehingga pendidikan yang diberikan kepada perempuan berguna dalam kehidupan rumah tangganya pula. Sebagaimana surat R.A. Kartini Nona E.H. Zeehandelaar pada 11 Oktober 1901, berikut:

Ketika urusan rumah tangga dibebankan kepada perempuan, maka sudah menjadi keharusan untuk mengajarkan terlebih dahulu kepada perempuan untuk berhemat apabila pemerintah ingin melihat rakyatnya hemat. Apa gunanya orang laki-laki belajar berhemat jika perempuan sebagai pengatur rumah tangga tidak tahu nilai uang?. (Kartini, 2018: 191)

Pendidikan yang diberikan kepada perempuan bukanlah sarana bagi perempuan untuk menyaingi laki-laki. Tetapi dengan pendidikan tersebut perempuan mampu mengemban semua tugasnya dengan baik, perempuan yang cakap. Seperti surat R.A. Kartini kepada Tuan Prof. Dr. G.K. Anton dan Nyonya pada 4 Oktober 1902, sebagai berikut:

Kami memohon dengan sangat supaya di sini diusahakan pengajaran dan pendidikan bagi anak-anak perempuan. Bukanlah karena kami hendak menjadikan anak-anak perempuan menjadi saingan orang laki-laki, melainkan karena kami yakin akan pengaruh besar yang mungkin datang dari kaum perempuan. Kami hendak menjadikan perempuan menjadi lebih cakap dalam melakukan tugas besar yang diletakkan oleh ibu Alam sendiri ke dalam tangannya agar menjadi ibu yang menjadi pendidik anak-anak mereka. (Kartini, 2018: 386)

Dari beberapa upaya R.A. Kartini untuk meningkatkan harkat dan martabat perempuan, pendidikanlah yang merupakan kunci utama untuk mengembalikan harkat dan martabat perempuan.

b. Perempuan Berbudi Luhur

Dalam sebuah pendidikan tentunya tidak akan dikatakan berhasil apabila yang dididik kecerdasan semata. Tetapi dalam sebuah pendidikan harus mengutamakan moral peserta didik. Sebagimana yang digagas oleh R.A. Kartini, tertuang dalam suratnya kepada Nyonya R.M. Abendanon - Mandri pada 21 Januari 1901, sebagai berikut:

...Saya merasa demikian, bahwa dengan mengembangkan fikiran saja tugas pendidik belum selesai, belum boleh selesai. Seorang pendidik harus juga 


\section{Uliyatul Marfu'ah}

memelihara pembentukan budi pekerti, walaupun tidak ada hukum secara pasti mewajibkan melakukan itu. (Kartini, 2018: 123)

Kecerdasan budi dan jiwa harus dilatih, diperjuangkan, dan diajarkan dalam waktu yang panjang. Tidak bisa secara langsung dapat dipahami atau dilaksanakan oleh anak-anak. Sebagaimana kita tahu, bahwasanya pendidikan budi dan jiwa perlu contoh nyata dari pendidik itu sendiri. Selanjutnya R.A. Kartini mengungkapkan bahwa dengan pendidikan diharapkan mampu membentuk watak perempuan, selalu bercita-cita. Sebagaimana surat R.A. Kartini kepada Tuan E.C. Abendanon pada 15 Agustus 1902, yaitu:

...Saya berharap dengan pendidikan dapat membantu pendidikan watak, dan yang paling utama adalah cita-cita. Cita-cita ini wajib dikembangkan oleh pendidikan, terus-menerus, tak henti-hentinya. (Kartini, 2018: 341)

Demikianlah cara R.A. Kartini dalam meningkatkan harkat dan martabat perempuan, yaitu memberikan pendidikan yang berbudi luhur. Dengan begitu, perempuan akan selalu dihormati. Tidak memandang warna kuliat, kekayaan, pangkat dan lain sebagainya.

c. Perempuan Berketerampilan

Pada zaman R.A. Kartini minim sekali orang ahli dalam bidang kesehatan. Maka dari itu, R.A. Kartini menginginkan sekolah yang akan didirikannya mengajarkan tentang itu semua. Hal ini bertujuan untuk mengurangi banyaknya kematian sebab keterlambatan dalam menolong. Seperti keterampilan membalut luka, keterampilan mengobati, keterampilan membatu melahirkan, dan keterampilanketerampilan lainnya. Sebagaimana tertuang dalam suratnya kepada Nona E.H. Zeehandelaar pada 25 April 1903, yaitu:

...Rencana kami demikian besar, kalau sekolah itu sudah ada dan semuanya berjalan baik, di sekolah itu akan kami buka kursus untuk memndidik dokterdokter perempuan, juru rawat dan dukun beranak. Yang akan mengajar dokterdokter militer itu dan pimpinan kursus Roekmini. Kursus yang demikian itu hanyalah dapat berdiri di sini di bawah pimpinan seorang perempuan yang beradab dan terpelajar. (Kartini, 2018: 464)

Dalam surat R.A. Kartini yang ditujukan Nonya N. Van Kol pada Agustus

1901, R.A. Kartini mengungkapkan. Bahwa adiknya, R.A. Roekmini akan belajar seni lukis untuk perkembangan lukisan bumiputra, sebagai berikut:

Adik perempuan saya Roekmini sangat suka sekali menggambar, dan khayalannya yang paling tinggi ialah masuk akademi seni lukis, agar kelak dapat mengabdikan diri kepada perkembangan seni bumiputra. (Kartini, 2018: 111)

Dari beberapa surat R.A. Kartini yang menunjukkan perlunya keterampilan bagi perempuan tersebut dapat memiliki makna pula, bahwa seorang perempuan akan selalu menjunjung tinggi harkat dan martabat yang dimilikinya dengan cara 
mengabdikan diri untuk kemaslahatan umat. Seperti yang terkandung dalam surat R.A. Kartini di atas, dengan keterampilan balut membalut luka, mengetahui cara merawat orang sakit, mengabdikan diri pada perkembangan seni bumiputra dan lain sebagainya.

d. Perempuan Bebas yang Beradab dan Terpelajar

Tentu semua orang menginginkan akan suatu kebebasan, termasuk perempuan. Kebebasan yang dimaksud yaitu kebebasan dalam konteks kebaikan. Seperti contohnya, dulu zaman R.A. Kartini perempuan tidak diperbolehkan untuk mengungkapkan pendapatnya, baik dalam bentuk tulisan ataupun lisan. Hal ini tergambar dalam surat R.A. Kartini kepada Nona E.H. Zeehandelaar pada 20 Mei 1901, yaitu:

...Hal itu akan sangat mengyedihkan! Aduh, kamu tidak tahu, betapa tangan ini menyala ingin menulis menyambut usul bagus Direktur Pengajaran dan tentang pendidikan yang telah diusulkan bagi anak tak mampu, saya harus menutup mulut dan tidak mengangkat pena. Saya tidak boleh mengatakan pendapat saya mengenai perkara-perkara penting itu, paling sedikit tidak boleh melalui surat kabar. (Kartini, 2018: 134)

R.A. Kartini juga mengajarkan bahwa perempuan bumiputra harus bebas, tidak tergantung pada orang lain. Hidup mandiri. Sebagaimana tertuang dalam suratnya kepada Nyonya R.M. Abendanon - Mandri pada 3 Januari 1902, berikut:

Anak perempuan bumiputra tidak perlu bergantung kepada keluarga jika dia sendiri tidak menginginkannya. Adakah yang lebih hina lagi selain bergantung pada orang lain? Apabila sebelumnya ia mempelajari suatu kepandaian, maka sekarang ia sudah bebas dan mandiri!. (Kartini, 2018: 221)

R.A. Kartini mengungkapkan hal yang serupa yaitu tentang seruan kepada perempuan untuk mengungkapkan apa yang dirasakan dan difikirkannya. Surat tersebut kepada Nyonya R.M. Abendanon - Mandri pada 27 Naret 1902, yaitu:

Sungguh, perempuan harus meneriakkan suaranya! Masih bisakah dengan tenang orang mengatakan "keadaan mereka baik", jika orang melihat dan mengetahui semua yang telah kami lihat dan kami ketahui itu?. (Kartini, 2018: 264)

Dalam surat-surat di atas menunjukkan bahwa R.A. Kartini sangat menginginkan perempuan bebas, bebas dalam konteks yang baik. Berdiri sendiri tanpa bergantung pada orang lain dan mampu untuk memilih seseorang untuk menjadi suaminya.

e. Laki-laki Bekerjasama dengan Perempuan

Tidak ada pembedaan antara laki-laki dan perempuan. Itulah salah satu keinginan R.A. Kartini. Laki-laki dan perempuan sama-sama makhluk ciptaan Tuhan dengan segala kelebihan dan kekuranganya masing-masing. Laki-laki dan perempuan 


\section{Uliyatul Marfu'ah}

adalah kawan yang bagus untuk bekerjasama. Baik bekerjasama dalam keluarga maupun bekerjasama sebagai mitra kerja. Seperti yang diungkapkan oleh R.A. Kartini dala suratnya kepada Tuan Prof. Dr. G.K. Anton dan Nyonya pada 4 Oktober 1902, yaitu:

Alangkah bahagianya seorang lelaki bila istrinya bukan hanya menjadi pengurus rumah tangganya dan ibu anak-anaknya saja, melainkan juga jadi sahabatnya, yang berminat pada pekerjaannya, menghayati bersama suaminya. Bagi kaum laki-laki hal ini tentulah tak ternilai harganya. (Kartini, 2018: 284)

Pada zaman dulu, persahaban antara laki-laki dan perempuan yang belum menikah sangatlah mustahil. Persahabatan tersebut dianggap tidak mungkin terjadi. Namun R.A. Kartini yakin bahwasanya itu semua dapat diperbaiki, seperti yang terangkum dalam suratnya kepada Nyonya M.C.E. Ovink - Soer pada awal tahun 1900, yaitu:

Persahabatan antara perempuan yang belum kawin dengan laki-laki yang sudah kawin atau belum, dianggap tidak mungkin terjadi. Kelak kalau kami sudah merebut kebebasan kami, dapatlah kami bersahabat dengan kaum laki-laki. Kakak saya kenal mereka semua, pribadi atau melalui surat-menyurat. Kami tahu, bahwa ada orang laki-laki yang berpikiran dan menghargai perempuan yang maju. Saya pernah mendengar orang laki-laki, pegawai Bumiputra terkemuka mengatakan, adalah suatu pertolongan dan bantuan besar sekali bagi orang-orang laki-laki, jika perempuan berbudi tinggi dan terpelajar. (Kartini, 2018: 54)

Dulu seorang gadis tidak boleh dekat-dekat laki-laki, dan ini menyebabkannya seorang tidak terbiasa bersama-sama laki-laki. Hal tersebut akan menghambat terwujudnya cita-cita untuk saling bekerjsama memajukan bangsa. Terdapat pada surat R.A. Kartini kepada Nona E.H. Zeehandelaar pada 17 Mei 1902, yaitu:

... Dan seorang gadis senantiasa harus menjauhi orang laki-laki, maka akhirnya pasti orang merasa sesak nafas untuk bertemu dengan makhluk-makhluk itu. Ini tidak boleh dibiarkan terus. Prasangka itu harus lenyap. Jikalau demikian keadaannya, bagaimana kami akan dapat bekerja sama dengan kaum laki-laki? Ini cita-cita kami yang muluk. (Kartini, 2018: 277)

R.A. Kartini berkeinginan, kelak bila dirinya memiliki anak, akan didiknya dengan baik. Mengajarkan untuk saling memandang sama antara laki-laki dan perempuan. Hal itu diungkapkan oleh R.A. Kartini dalam suratnya kepada Nona

E.H. Zeehandelaar juga pada 23 Agustus 1900, sebagai berikut:

Saya akan mengajarkan anak-anak saya baik laki-laki maupun perempuan untuk saling memandang sebagai mahkluk yang sama. Saya akan memberikan pendidikan yang sama kepada mereka, tentu saja menurut bakatnya masingmasing. Untuk membuat anak gadis menjadi perempuan baru misalnya, saya tidak akan memaksa untuk belajar bila dia tidak menyukai dan tidak berbakat. Tetapi dengan mengurangi haknya dengan mendahulukan kakaknya yang lakilaki, tidak akan! Lagi pula saya bermaksud akan menghapuskan batas 
menggelikan antara laki-laki dan perempuan yang dibuat sedemikian cermatnya. (Kartini, 2018: 86)

R.A. Kartini mengungkapkan bahwa perempuan dan laki-laki memiliki kesetaraan yang sama, dan semakin kuat manfaatnya jika berkerja sama antar keduanya, sebagaimana dalam suratnya yang ditujukan kepada Nona Zeehandelaar pada tanggal 11 Oktober 1901, sebagai berikut:

Kaum muda masa sekarang, tiada pandang laki-laki atau perempuan, wajiblah berhubungan. Masing-masing sendiri-sendiri memang dapat berbuat sesuatunya akan memajukan bangsa kami, tetapi apabila kita berkumpul bersatu, mempersatukan tenaga, bekerja bersama-sama, tentu usaha itu lebih besar hasilnya. Bersatu kita kukuh teguh. (Kartini, 2018: 129)

Jadi R.A. Kartini menginginkan seorang laki-laki dan perempuan menjadi teman yang baik untuk bekerjasama. Sahabat dalam kerja baik di rumah maupun rekan kerja di luar. Bekerjasama untuk cit-cita yang besar. Menjadikan bangsa yang lebih beradab untuk masa yang akan mendatang.

f. Perempuan Berpengetahuan Ilmu Keagamaan

Setelah penulis membaca secara keseluruhan dari kumpulan surat-surat R.A. Kartini yang terangkum dalam buku Habis Gelap Terbitlah Terang merasakan bahwa setelah R.A. mengenal Islam secara utuh, hidupnya menjadi lebih yakin dan optimis, dan hidup dengan damai. Sebagaimana suratnya kepada Tuan E.C. Abendanon pada 15 Agustus 1902, yaitu:

Seandainya saya bisa mengatakan yang sebenarnya, betapa tenang dan damainya hati kami. Betapa kami bersyukur dan bahagia. Betapa aman dan tenang perasaan kami, setelah kami menemukan Dia, setelah kami tahu, merasa bahwa selalu ada Tuhan dekat kami dan menjaga kami, tempat kami berlindung dalam hidup kami selanjutnya. Itulah yang kami rasakan. (Kartini, 2018: 343)

R.A. Kartini beberapa kali mengungkapkan bahwa dia yakin akan kuasaan Tuhan, dan percaya bahwa semua yang terjadi di muka bumi ini merupakan takdir yang telah ditetapkan oleh Tuhan, manusia hanya bisa berusaha dan akhir dari usaha tersebut adalah keputusan Tuhan. Sebagaimana dalam suratnya kepada Nyonya R.M. Abendanon - Mandri pada 27 Oktober 1902, sebagai berikut:

Nyonya tentu telah pernah mendengar tentang ketabahan bangsa Jawa, sekalipun mereka menanggung nasib yang sangat buruk. "Sudah takdir" katanya dan itulah yang menghibur dan menyabarkan hatinya. "Nasib tiap manusia telah ditentukan sebelum ia lahir di dunia. Untung malangnya telah ditakdirkan sebelum ia lahir. Tiada manusiapun yang sanggup menolak apa yang sudah ditakdirkan Allah. Tetapi sebelum kecelakaan itu terjadi, wajiblah dengan sungguh-sungguh terikhtiar menolaknya. Jika kecelakaan itu datang juga menimpa sudahlah, itu "takdir". Dan tidak ada sesuatupun di dunia ini yang sanggup melawan takdir. (Kartini, 2018: 406) 
Percayaan R.A. Kartini akan Tuhan menjadikannya untuk tidak bergantung pada manusia, hanya kepada Allah-lah tempat berlindung, sebagaimana diungkapkan R.A. Kartini dalam suratnya kepada Tuan Abendanon pada tanggal 17 Agustus 1902, sebagai berikut:

Tetapi sekarang ini, kami tiada mencari pelipur hati pada manusia, kami berpegangan teguh-teguh pada tangan-Nya. Maka hari gelap-gulita pun menjadi terang dan angin ributpun menjadi sepoi-sepoi. (Kartini, 2018: 234)

R.A. Kartini memiliki keyakinan bahwa semua agama mengajarkan kebaikan.

Manusia sama dalam pandangan Allah SWT. Selaras apa yang diinginkannya, tidak ada perbedaan laki-laki dan perempuan. Sebagaimana isi surat R.A. Kartini kepada Nyonya N. Van Kol pada 21 Juli 1902, yaitu:

Agama yang dimaksud supaya memberi berkah. Untuk membentuk tali silaturahmi antara semua makhluk Allah, berkulit putih atau coklat. Tidak pandang pangkat, perempuan atau laki-laki, kepercayaan, semuanya kita ini anak Bapak yang seorang itu, Tuhan Yang Maha Esa! Tiada Tuhan kecuali Allah! Kata kami umat Islam, dan bersama-sama yang yang beriman, kaum monotheis; Allah itu Tuhan, Pencipta Alam Semesta. (Kartini, 2018: 324)

R.A. Kartini meyakini bahwa Tuhan selalu bersama hambanya. Selalu melindungi hambanya. Selalu mendengarkan doa-doa yang dipanjatkan oleh hambanya, sebagaimana suratnya kepada Nyonya H.G. de Booij - Boissevain pada 21 Maret 1902, yaitu:

Untuk apa kami berpusing-pusing dengan manusia, sedangkan kami tahu bahwa kami dilindungi Tuhan! Yang kami kerjakan ini adalah pekerjaan-Nya dan Dia akan menganugrahi kami tenaga untuk melakukan pekerjaan itu. Kami bersedia berbuat apapun, bersedia memberikan diri kami sendiri. Bersedia menerima luka hati. Air mata, darah akan mengalir banyak, tetapi tidak apalah. Itu semuanya akan menuju ke kemenangan. Tidak akan ada cahaya tanpa didahului gelap, hari fajar muncul seletah malam. Setelah kami menemukanNya, rasanya seolah-olah hidup kami menjadi lebih bagus, panggilan hidup kami lebih indah, lebih mengasyikkan, lebih luhur. Semangat kudus itu memberi berkah kepada barang apa juga pun. (Kartini, 2018: 249)

Dari keyakinan yang kuat tersebutlah R.A. Kartini pernah mengungkapkan

bahwa dirinya ingin menggunakan gelar yang paling tinggi, yaitu hamba Allah. Yaitu dalam suratnya kepada Nyonya R.M. Abendanon - Mandri pada 1 Agustus 1903, sebagai berikut:

Saya sepertinya pernah mengatakannya kepada Ibu jika saya telah lama mengesampingkan segala kepentingan pribadi? Ingin sekali saya menggunakan gelar tertinggi, yaitu hamba Allah. Sekarang hidup menuntut janji itu. Tidak ada sesuatu yang terlalu pahit, terlalu berat, terlalu keras bagi kami, apabila kami dengan perbuatan itu dapat membantu sedikit pembangunan tugu peringatan yang indah yaitu: kebahagiaan bangsa. (Kartini, 2018: 488)

Kayakinan R.A. Kartini tentang Islam menjadikannya lebih tenang dalam menjalani kehidupan. Lebih optimis dalam meraih cita-cita. Keyakinannya terhadap 
takdir Tuhan, menjadikannya kuat untuk terus berusaha tanpa mengenal putus asa. Semua itu menunjukkan bahwa jika perempuan memiliki kepercayaan agama yang baik dan menjalankan perintah Tuhan serta menjauhi larangannya menjadikan harkat dan martabat perempuan terjaga dengan baik. Untuk kehidupan dulu, sekarang dan yang akan datang, agama adalah jawabannya.

g. Menghapus Sistem Kasta pada Masyarakat

Sistem yang merendahkan orang kecil atau rakyat biasa yang tidak berpangkat. Rela memberikan nyawanya untuk tuannya. Dalam konteks ini perempuan yang sangat dirugikan. Karena berbicara tentang kasta, orang yang tidak berpangkat akan selalu ditindas, apalagi seorang perempuan. Semakin diperlakukan dengan semaunya oleh tuannya, terutama seorang laki-laki. R.A. Kartini tidak suka dengan kebiasaan masyarakatnya yang selalu mengagung-agungkan orang yang berpangkat. Sebagaimana suratnya kepada Nona E.H. Zeehandelaar pada 12 Januari 1900, yaitu:

Saya tidak pernah mengizinkan wanita-wanita yang lebih tua daripada saya, yang tingkat derajatnya lebih rendah menghormati saya atas dasar hak saya. Saya tahu, mereka senang berbuat demikian. Meskipun saya jauh lebih muda daripada mereka, tetapi saya seorang keturunan bangsawan yang sangat mereka junjung tinggi. Mereka rela mengorbankan harta kekayaannya untuk bangsawan itu. Mengharukan hati, bagaimana lekat dan setianya bawahan kepada pembesar-pembesarnya. Sangat tertusuk perasaan saya melihat orangorang yang lebih tua dari saya berjongkok-jongkok untuk saya. (Kartini, 2018: 45)

R.A. Kartini mengatakan sudah biasa memperoleh pujian dan sanjungan. Orang-orang dewasa merangkak di bawahnya, mencium kakinya sejak dirinya masih kecil. Sebagaimana diungkapkan oleh R.A. Kartini dalam suratnya kepada Tuan H.H. Van Kol pada 10 Agustus 1902, yaitu:

...Sejak masa kanak-kanak kami telah biasa sekali dengan rayuan dan sanjungan. Kami muak terhadap perbuatan orang-orang yang demikian itu. Sedih benar hati kami melihat orang tua-tua, orang-orang yang sudah beruban merangkak di depan anak-anak. Itu adat! Kami tidak dapat menolaknya semua, tapi sekali-kali tidak menghendaki orang mencium kaki kami. (Kartini, 2018: 333)

Tidak ada batasan antara orang berpangkat dan tidak, rakyat biasa bisa bergaul dengan baik dan santai dengan R.A. Kartini adalah impiannya. Tidak ada orang yang lebih dewasa darinya merangkak dibawahnya, mecium kakinya dan lain sebagainya.

Dari ketujuh konsep harkat dan martabat yang telah diuraikan penulis di atas dapat disimpulkan bahwa benang merah dari ketujuh konsep tersebut yaitu tentang 


\section{Uliyatul Marfu'ah}

keinginan atau pemikiran-pemikiran R.A. Kartini tentang pendidikan, kesetaraan antara laki-laki dan perempuan serta kebebasan untuk perempuan. Hal tersebut bertujuan untuk mengembalikan harkat dan martabat perempuan yang telah dibawanya sejak lahir namun dirampas oleh adat dan kebiasaan yang tidak baik. Agar perempuan dalam mengembangkan potensi yang dimilikinya dapat terlaksana dengan maksimal baik dalam ranah individu, keluarga, ataupun sosial.

\section{Relevansi Konsep Harkat dan Martabat Perempuan dalam Buku Habis Gelap Terbitlah Terang Karya R.A. Kartini dengan Pendidikan Islam}

Islam merupakan agama yang sangat menghargai dan menghormati laki-laki dan perempuan di hadapan Allah secara mutlak. Islam menghapus tradisi Jahiliyah yang begitu diskriminatif terhadap perempuan. Islam menganggap laki-laki dan perempuan sebagai mahkluk Allah yang setara, dan bahkan satu sama yang lainnya saling membutuhkan dan saling melengkapi. Islam sebagai agama rahmatal lil alamin memposisikan perempuan pada tempat yang mulia. Al-Qur'an mengajarkan bahwa semua manusia sama dalam pandangan Allah SWT, yang membedakan hanyalah tingkat keimanan dari seseorang tersebut. Islam memberikan kebebasan perempuan secara penuh dalam menentukan pasangan hidupnya, bahkan walinya dilarang menikahkannya secara paksa, jadi pernikahan seorang gadis tidak akan terlaksana apabila belum mendapatkan izin dan persetujuannya. Perempuan dan laki-laki memiliki kedudukan yang sama di depan hukum, bahkan Islam memberikan hak yang sama kepada perempuan dalam mengakhiri kehidupan berumah tangga yaitu dengan cara khulu'. (Agus Hanafi, 2015: 15-17)

Beberapa ayat Al-Qur'an yang menunjukkan bagaimana kedekatan hubungan antara laki-laki dan perempuan, misalnya dalam hal perkawinan yaitu sebagai berikut:

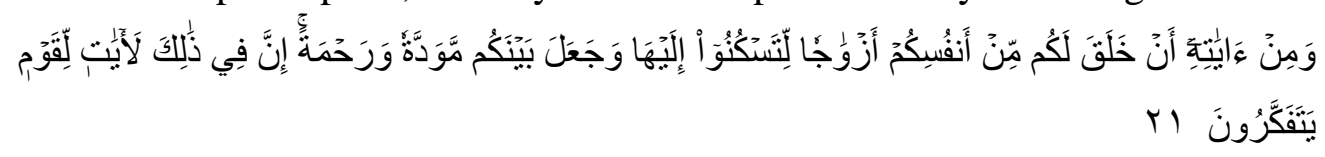

Dan di antara tanda-tanda kekuasaan-Nya ialah Dia menciptakan untukmu isteriisteri dari jenismu sendiri, supaya kamu cenderung dan merasa tenteram kepadanya, dan dijadikan-Nya diantaramu rasa kasih dan sayang. Sesungguhnya pada yang demikian itu benar-benar terdapat tanda-tanda bagi kaum yang berfikir.(Q.S. Ar-Rum:21) (Al-Qur'an Qordoba, 2018: 406)

Dari ayat di atas dapat ditarik kesimpulan bahwa begitu dekatnya hubungan antara laki-laki dan perempuan berdasar asal kejadian, bahwa perempuan dan laki-laki berasal dari asal yang sama, bahkan diri yang sama. Karena itu rasa saling membutuhkan antara laki-laki dan perempuan dan adanya kecenderungan untuk hidup bersama, hal ini merupakan fitrah yang telah ada sejak awal penciptaan manusia. 
Ayat ini juga mengisyaratkan kesetaraan dalam hak mendapat kasih sayang dan kedamaian dengan jalan saling menerima. Tuhan tidak menciptakan yang satu untuk mengeksploitasi yang lain, dan kebahagiaan yang satu di atas penderitaan yang lain, tetapi justru dengan saling mengasihi dan menyayangi, mereka akan mendapatkan kedamaian. Tidak ada kodrat menjadikan perempuan harus tunduk kepada laki-laki maupun sebaliknya. Laki-laki dan perempuan harus tunduk kepada kebenaran dan harus bersama-sama menegakkan keadilan. (A Agus Hanafi, 2015: 17-18)

Kesetaraan dan kebebasan yang dimilki laki-laki dan perempuan yang telah dijelaskan di atas juga berlaku dalam hal pendidikan. Laki-laki dan perempuan berhak untuk memperoleh pendidikan.

Dalam pendidikan Islam juga mengajarkan bahwa pendidikan yang utama yaitu pendidikan akhklak. Percuma jika hanya pintar tetapi tidak berakhlak. Nabi bersabda tentang akhlak yaitu dalam hadits yang diriwayatkan oleh Bukhari, sebagai berikut:

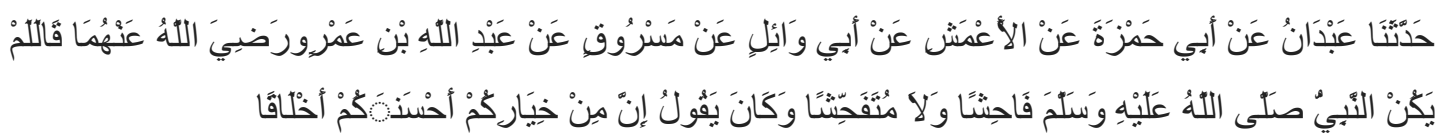

Telah bercerita kepada kami 'Abdan dari Abu Hamzah dari Al A'masy dari Abu Wa'il dari Masruq dari 'Abdullah bin 'Amru radliallahu 'anhu berkata: "Nabi shallallahu 'alaihi wasallam tidak pernah sekalipun berkata kotor (keji) dan juga tidak pernah berbuat keji dan beliau bersabda: "Sesungguhnya di antara orang yang terbaik dari kalian adalah orang yang paling baik akhlaknya. (HR. Bukhari) (Bukhari Umar, 2012: 43)

Rasulullah SAW di utus ke muka bumi ini slah satu misi yang diembannya adalah untuk menyempurnakan akhlak atau budi pekerti manusia, dengan suri tauladan yang baik, bukan sekadar anjuran ataupun perintah saja. Nabi Muhammad SAW memiliki dan mencontohkan akhlak yang sangat terpuji yang dikagumi oleh kawan maupun lawannya. Dalam Al-Qur'an surat Al-Qalam ayat empat menggambarkan bagaimana akhlak Nabi Muhammad SAW, yaitu:

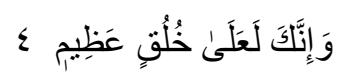

Sesungguhnya engkau (Muhammad) berbudi pekerti yang luhur. (Q.S. Al-Qolam: 4) (Al-Qur'an Qordoba, 2018: 564)

Tujuan utama dari Pendidikan Islam yaitu pembentukan akhlak yang mulia, yaitu budi pekerti yang dapat menghasilkan orang-orang yang bermoral, yaitu jiwa yang bersih, rendah hati, percaya diri, sopan santun dalam setiap pembicaraan dan perbuatan, bijaksana, berkemauan keras, menghormati hak orang lain, itulah salah satu tugas Islam dan ummatnya. 


\section{Uliyatul Marfu'ah}

Selain mengenai akhlak, dalam hadits Nabi juga ada yang menjelaskan tentang anjuran untuk memberikan anak keterampilan yaitu dalam hadits Nabi yang diriwayatkan oleh, sebagai berikut:

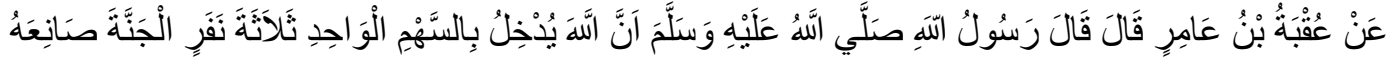

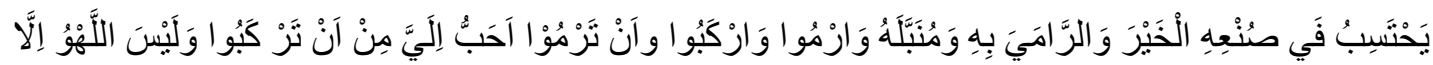

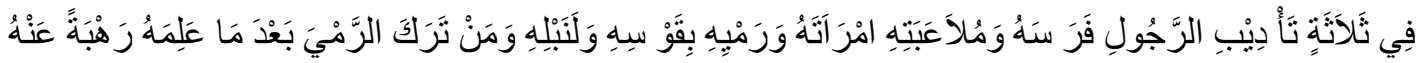

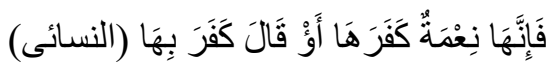

Dari Uqbah bin Amir berkata: Rasulullah SAW bersabda: "Sesungguhnya Allah memasukkan tiga orang ke surga sebab satu panah, perbuatannya yang mengharapkan kebaikan dalam pembuatannya, pemanahnya dan pemberi anak panah. Panahlah dan berkendaraanlah dan panahanmu lebih aku cintai daripada engkau berkendaraan. Tidak ada permainan melainkan pada tiga perkara: pengajaran seseorang pada kudanya, bermain-main dengan istrinya dan memanah dengan busur dan anak panah. Barang siapa yang meninggalkan memanah setelah dia terampil karena benci, maka seungguhnya ia nikmat yang dikufuri atau bersabda: ia mengkufuri. (HR. al-Nasai dan al-Turmudzi) (Suryani, 2012: 69)

Sebagai contoh bahwasannya perempuan pada zaman Nabi juga mendapatkan haknya yaitu memperoleh pendidikan, dapat dillihat dengan adanya tokoh-tokoh perempuan muslim yang juga ikut berperan dalam dunia pendidikan. Pada masa Rasulullah, Aisyah-istri Rasulullah masuk ke dalam kelompok intelektual Islam. Beberapa literatur menjelaskan bahwa Aisyah adalah seorang perempuan yang cerdas.

Pada bidang Hadis, Aisyah r.a menempati posisi ke 4 dalam jumlah hadits yang diriwayatkan, yaitu sebanyak 2210 hadits. Jumlah tersebut mengalahkan jumlah hadits yang diriwayatkan sahabat lain yang usianya jauh lebih tua dari beliau. Selain itu Aisyah juga mampu menafsirkan, melakukan penalaran dan mengambil kesimpulan. Dalam lintas sejarah pendidikan Islam juga dijelaskan bahwa Islam memang memberikan pengajaran juga terhadap perempuan, hal ini terbukti dengan adanya perempuan-perempuan yang berintelektual diantaranya:

1) Khadijah binti Khuwailid, seorang ummul mukminin dan saudagar terdidik yang selalu mendampingi Nabi Muhammad SAW dan berjuang dalam menyiarkan Islam.

2) Aisyah binti Abu Bakar, perempuan cerdas memiliki ilmu pengetahuan dan telah meriwayatkan lebih dari 1000 hadist dengan periwayatan langsung, Aisyah juga seorang yang ahli dalam bidang fiqih, tafsir, kedokteran dan syair-syair.

3) Asma binti Abu Bakar, perempuan pemberani yang selalu megantarkan makanan kepada Nabi ketika akan hijrah. 
4) Hafsah binti Umar, Fatimah Az-Zahra, Sakinah binti Husein merupakan perempuan pencinta ilmu pengetahuan.

5) Nasihah binti Ka'ab, Aminah binti Qays al-Gifariyah, Ummu Athiyah alAnshariyyah, Rabiyah binti Mas'ud merupakan perempuan yang ikut perang bersama Nabi, mereka bertugas merawat orang-orang yang sakit dan mengobati orang-orang yang terluka.

6) Al-Khansa', Hindu binti 'Atabah, Laila binti Salma, Siti binti Husein merupakan perempuan yang mahir di bidang syair dan kesastraan.

Jadi jelaslah, bahwa Islam juga membenarkan jika dikatakan Pendidikan itu bersifat nondiskriminatif bahkan Islam menganut konsep kemitrasejajaran dalam menuntut ilmu. Islam tidak hanya membenarkannya melalui teori saja, bahkan dalam prakteknya (history) juga yang dapat kita lihat dalam perbincangan sejarah peradaban Islam. (Megawati, 2016: 137-139)

Dari uraian di atas dapat disimpulkan bahwa konsep harkat dan martabat perempuan dalam pandangan R.A. Kartini sangat relevan dengan tujuan pendidikan Islam. Dimana konsep harkat dan martabat tersebut mendukung perempuan untuk mengembangkan potensi diri yang dimilikinya, baik dalam ranah individu, keluarga, sosial serta berkarya sehingga dapat dengan mudah terciptanya kepribadian yang seutuhnya bagi manusia khususnya untuk perempuan dalam konteks ini.

\section{E. KESIMPULAN}

Berdasarkan analisis data yang yang telah disajikan oleh penulis maka dapat disimpulkan bahwa konsep harkat dan martabat perempuan dalam pandangan R.A. Kartini ada tujuh macam yaitu: perempuan berpendidikan, perempuan berbudi luhur, perempuan berketerampilan, perempuan bebas yang beradab dan terpelajar,laki-laki bekerjasama dengan perempuan, perempuan yang berpengetahuan ilmu agama, serta menghapus sistem kasta di masyarakat. Inti dari ketujuh konsep yang menarik tersebut yaitu prinsip kebebasan. Perempuan memiliki kebebasan dalam mengembangkan bakat, berkarya, berkarir dan berkontribusi dalam masyarakat. Dalam proses tersebut perempuan memiliki nilai-nilai yang tinggi dimana R.A. Kartini sebagai basis filosofi utama. Konsep harkat dan martabat tersebut merupakan kombinasi dari budaya Jawa (Indonesia), ajaran Islam dan modernitas dari barat.

Dengan demikian pandangan R.A. Kartini terhadap konsep harkat dan martabat perempuan sangat relevan dengan tujuan pendidikan Islam. Dimana konsep harkat dan 


\section{Uliyatul Marfu'ah}

martabat tersebut mendukung perempuan untuk mengembangkan potensi diri yang dimilikinya, baik dalam ranah individu, keluarga, social dan berkarya sehingga dapat dengan mudah terciptanya kepribadian yang seutuhnya bagi manusia khususnya untuk perempuan dalam konteks ini.

\section{DAFTAR PUSTAKA}

Abidin, Zainal. 2015. Kesetaraan Gender dan Emansipasi Perempuan dalam Pendidikan Islam. Jurnal Tarbawiyah, 12 (1): 9-10.

Ahdiah, Indah. 2013. Peran-Peran Perempun dalam Masyarakat. Jurnal Acamedica, 5 (2): 1088.

Al-Qur'an Cordoba. 2018. Al-Qur'an dan Terjemahnya. Bandung: Cordoba.

Al-rasyidin, dkk. 2005. Filsafat Pendidikan Islam. Jakarta: Ciputat Press.

Arif, Arifuddin. 2008. Pengantar Ilmu Pendidikan Islam. Jakarta: Kultura.

Djaelani, Moh Solikodin. 2012. Peran Pendidikan Islam dalam Keluarga dan Masyarakat. Jurnal Widya Sosiopolitika, 1 (2): 101.

Fauzia, Amelia. 2004. Tentang Perempuan Islam: Wacana dan Gerakan. Jakarta: Gramedia Pustaka Utama.

Gunawan, Heri. 2014. Pendidikan Islam Kajian Teoritis dan Pemikiran Tokoh. Bandung: PT Remaja Rosdakarya.

Hanafi, Agustin. 2015. Peran Perempuan dalam Islam. Jurnal Studi Anak dan Gender, 1 (1): $15-18$

Hasan, Hamka. 2009. Tafsir Jender: Studi Perbandingan antara Tokoh Indonesia dan Mesir. Jakarta: Badan Litbang dan Diklat Departemen Agama RI.

Hasyim, Syafiq. 2001. Hal-Hal Yang Tak Terpikirkan Tentang Isu-Isu Perempuan dalam Islam. Bandung: Mizan.

Kartini. 2018. Habis Gelap Terbitlah Terang. diterj. oleh Armijn Pane. Yogyakarta: Narasi.

Khobir, Abdul. 2009. Pendidikan Agama Islam di Era Globalisasi. Jurnal Forum Tarbiyah, 7 (1): 2.

Lembaga Darut-Tauhid. 2001. Wanita dalam Pandangan Yahudi, Kristen, Marxisme, dan Islam. Jakarta: Hikmah.

Megawati. 2016. Konsep pendidikan perempuan perspektif R.A. Kartini dan relevansinya dengan pendidikan Islam. dalam Skripsi. Surabaya: UIN Sunan Ampel. 
Mustikawati, Citra. 2015. Pemahaman Emansipasi Wanita (Studi Hermeneutika Makna Emansipasi Wanita dalam Pemikiran R.A. Kartini pada Buku Habis Gelap Terbitlah Terang. Jurnal Kajian Komunikasi, 3 (1): 66.

Nafriandi. 2016. Perempuan di Ruang Publik dalam Perspektif Hadis. Jurnal Kafaah, 6 (1): 61.

Roqib, Moh. 2009. Ilmu Pendidikan Islam. Yogyakarta: Lkis

Shihab, M Quraish. 2005. Perempuan. Jakarta: Lentera Hati.

Suryani. 2012. Hadis Tarbawi. Yogyakarta: Teras.

Umar, Bukhari. 2012. Hadis Tarbawi. Jakarta: Amzah. 